\title{
BEING MODERATE MUSLIMS IN NON-MUSLIM COMMUNITY: AN INTER-RELIGIOUS DIALOGUE IN CHRISTIAN EDUCATIONAL INSTITUTION
}

\author{
Ahmad Madkur \\ Titut Sudiono
}

Institut Agama Islam Negeri (IAIN) Metro

Jl. Ki. Hajar Dewantara 15 A Kampus Iring Mulyo, Metro Timur

Kota Metro 34111

email: ahmadmadkur@metrouniv.ac.id dan sudiono24@gmail.com

\begin{tabular}{|c|c|c|}
\hline Diterima: & Revisi: & Disetujui: \\
15 April 2019 & 28 April 2019 & 05 Mei 2019 \\
\hline
\end{tabular}

\begin{abstract}
Abstrak
Dialog lintas agama antara Muslim dan Non-Muslim di sekolah semakin menarik minat banyak ilmuwan. Penelitian ini bertujuan untuk menyelidiki peran guru dan siswa Muslim dalam dialog antaragama dan model pengajaran peacebuilding (pembangunan perdamaian) di sebuah sekolah Kristen. Ini adalah penelitian deskriptif kualitatif yang dilakukan di Sekolah Menengah Pertama Kristen (SMPK) Seputih Banyak, Lampung Tengah. Data dikumpulkan melalui observasi, wawancara mendalam dan dokumentasi. Kemudian, model Miles \& Huberman digunakan untuk menganalisis data. Temuan menunjukkan bahwa kebijakan sekolah sangat mendukung dialog antaragama di antara semua guru dan siswa yang, memang, memiliki agama yang berbeda. Guru pendidikan agama Islam mempromosikan Islam moderat untuk mendorong dialog antaragama ketika mengajar siswa Muslim dan berinteraksi dengan nonMuslim. Hal ini memberikan pengaruh yang positif terhadap dialog antaragama dan model pengajaran peace-building dikembangkan dan diterapkan di sekolah-sekolah.
\end{abstract}

Kata Kunci: Islam moderat, dialog antaragama, model pengajaran peaceBulding

\begin{abstract}
The inter-religious dialogue between Muslims and Non-Muslims at schools are increasingly attracting much interest of scholars. This paper aimed at investigating the role of Muslim teachers and students in interfaith dialogue and
\end{abstract}


peace-building instruction model at a Christian school. This was a qualitative descriptive research conducted at Christian Middle School (SMP Kristen) Seputih Banyak, Central Lampung. The data were collected through observation, indepth interviews and documentations. Then, Miles \& Huberman model was employed to analyze the data. The findings showed that the school policy strongly supported the interfaith dialogue among all teachers and the students who, indeed, possesed different faiths. The Islamic religious education teacher promoted the moderate Islam to encourage the interfaith dialogue when teaching Muslim students and interacting with non-Muslims. This positevely affected interfaith dialogue and the peace-building instruction model developed and implemented at the schools.

Keyword: Moderate Islam, interfaith dialogue, and peace-building instruction model

\section{A. Introduction}

Inter-religious dialogue plays a pivotal role in establishing harmonius lives. It has a great potential to grow tolerance ${ }^{1}$ among the various religion believers. The term inter-religious or interfaith dialogue refers to mutual, productive and positive relations between people of different religious traditions and faith, at both the individual and institutional levels. Augmented awareness of religious plurality, the prospective role of religion in conflict, and the growing place of religion in public life present imperative challenges that call for better understanding and cooperation among people of diverse faiths to raise acceptance of others and to better understand their identity. Such interfaith dialogue can take a wide diversity of forms, ranging from joint appeals by high-level religious leaders, to attempts to build up mutual understanding and the appreciation of shared values and interests, to grassroots efforts to encourage repentance and promote reconciliation. $^{2}$

1 Zoran Brajovic, 'The Potential of Inter-Religious Dialogue', in Peacebuilding and Civil Society in Bosnia- Herzegovina, ed. by Martina Fischer, 2006, pp. 185-214.

2 A Abdool and others, 'Inter-Religious Dialogue in Schools : A Pedagogical and Civic Unavoidability', HTS Teologiese Studies, 63.2 (2007), 543-60 <https://doi.org/ DOI: $10.4102 /$ hts.v63i2.211>. 
In Indonesia, the world's biggest Muslim country, the right to believe in religions are officially protected by the law. Indonesia has been able to develop a model of democracy compatible with a Muslimmajority country ${ }^{3}$. This is in line with Azra's notion regarding Indonesia's moderate Islam-compatibility with modernity, democracy, and plurality. ${ }^{4}$ Indonesian Muslims are well-known for their moderate Islam especially after $9 / 11$, when Indonesia was trying to instill Moderate Islam as their image in world politics. In contemporary Indonesian policy, the government has campaigned Islam to be conceived as 'moderate' and 'tolerant' as well as inherently compatible with democracy ${ }^{5}$.

As a Muslim democratic state, the existence of civil institutions and public civility are among the most essential factors. This situation reflects the development of the Indonesian social and political situation. During the last period of the 1990s, a number of Muslim scholars such as Abdurrahman Wahid, Nurcholish Madjid, and Dawam Rahardjo played an central role in shaping the Islamic discourse in the media. Likewise, Muslim organizations such as 'Nahdlatul Ulama' and 'Muhammadiyah', despite their massive challenges from puritant Islamists and fundamentalists ${ }^{6}$, are very influential in the grassroot peacemaking process.

One of the most efficient ways to promote interreligious mutual understanding and peacebuilding among the youth is by promoting and implementing the significance of interfaith dialogue at educational institution in any level. Nicolai and Triplehorn that there is a strong

${ }^{3}$ Robert W Hefner, Civil Islam (Princeton: Princeton University Press, 2000).

4 Azyumardi Azra, 'Indonesian Islam, Mainstream Muslims and Politics in Taiwan', in Taiwanese and Indonesian Islamic Leaders Exchange Project (Taiwan: The Asia Foundation, 2006), pp. 1-11.

5 Ahmad Rizky Mardhatillah Umar, 'A Genealogy of Moderate Islam: Governmentality and Discourses of Islam in Indonesia's Foreign Policy', Studia Islamika, 23.3 (2016), 399-433.

6 Herdi Sahrasad, 'Herdi Sahrasad Indonesian Pluralism And Democracy Under Challenge: A Social Reflection', AL_FIKR, 20.2 (2016), 256-78. 
correlation between the role of education and protection of young people from attitudes that may cause conflict. ${ }^{7}$

The issue of moderate Islam and interfaith dialogue in educational institutions has been investigated in a large and growing body of previous studies in specific focuses such as the challenges of Islamic education in promoting moderate Islam ${ }^{89}$, interfaith dialogue in higher education ${ }^{10}$, interfaith dialogue and religious education ${ }^{11}$, the role religious leaders ${ }^{12}$, moderate Islam meaning among an Egyptian university alumni13, and challenges and tensions in interfaith dialogue. ${ }^{14}$ Nevertheless, the focus on the interfaith dialogue, especially the role of Muslims in the practice of instructional activities are considered rare. Therefore, the present study attempted to figure out the role of moderate Muslim teachers and students in establishing good inter-faith dialogue and, in the pedagogic practices, the model of peacebuilding instruction at Christian Middle School Seputih Banyak, Central Lampung.

7 Susan Nicolai and Carl Triplehorn, The Role of Education in Protecting Children in Conflict (London: Humanitarian Practice Network (HPN), 2003).

8 Muhammad Zuhdi, 'Challenging Moderate Muslims: Indonesia's Muslim Schools in the Midst of Religious Conservatism', Religions, 9.310 (2018), 1-15 <https://doi.org/10.3390/rel9100310>.

9 Syamsun Ni'am, 'Pesantren: The Miniature of Moderate', IJIMS, Indonesian Journal of Islam and Muslim Societies, 5.1 (2015), 111-34.

10 Claire Holland, 'Interfaith Dialogue and Higher Education: Education for Peace', Journal of the Tertiary Campus Ministry Association, 6.2 (2016), 1-8.

11 Zainal Abidin Bagir, 'Interfaith Dialogue and Religious Education', in Asia-?Europe Meeting (ASEM) 4th Interfaith Dialogue, 2008, pp. 1-9.

12 Khairulnizam Mat Karim and Suzy Aziziyana Saili, 'Role of Religious Leader in Interfaith Dialogue towards Conflict Role of Religious Leader in Interfaith Dialogue towards Conflict Resolution: A Muslim Analysis on Christianity's Perspective', in International Conference on Social Science Research, ICSSR, 2015, pp. 273-88.

13 Judith Schlehe and Eva Nisa, The Meanings of Moderate Islam in Indonesia: Alignments and Dealignments of Azharites, Occasional Paper Series (Freiburg, 2016) $<$ https://www.researchgate.net/deref/http\%3A\%2F\%2Fwww.southeastasianstudies .uni-freiburg.de $\% 2$ Fpublications $\% 2$ Fop-series $>$.

14 Michael Fuseini Wandusim, 'Interfaith Dialogue and Christian Witness: Exploring the Challenges and Tensions Involved From a Ghanaian Perspective', Journal of Advocacy, Research and Education, 3.2 (2015), 19-20. 
This was a qualitative research employing case study approach. In a case study, a contemporary phenomenon is investigated within its natural setting. ${ }^{15}$ The phenomenon here means many objects of study such as a program, an event, an activity, a problem or an individual. In this present study, the phenomenon was the existence of moderate Muslims and their contribution to interfith dialogue. Then, the natural setting is the context within which this phenomenon appears. In this case, the natural setting was the Christian Middle School Seputih Raman, Central Lampung regency, Lampung.

To collect the data, observation, interviews and documentation were carried out. The writers directly went to the school and organized observations to see the real contexts (events, place, time and process) of the implementation of the inter-religious dialogue. In addition, the writers interviewed some stakeholders of the school, the principal, teachers, and students to see their perspectives on this phenomenon. The gathered data were subsequently analyzed by employing Miles and Huberman's model consisting of data collection, data reduction, data display and conclusion drawing. ${ }^{16}$

\section{B. Results and Discussion}

\section{Christian Middle School Seputih Raman: At a Glance}

This private school is located at Yos Sudarso Street, Rukti Harjo, Seputih Raman, Central Lampung Tengah, Lampung province. It was established in 1990 on a 1.026-meter area. Today, eighty two students (44 males and 38 females) with different religious backgrounds go to this school. It implements the 2013 Curriculum and full-day school system in which the instructional activities are held five days a week. The principal stated that the 2013 curriculum fits their goal of character

15 Kenneth Harling, "An Overview of Case Study," 2002, accessed July 12, 2018, http://www.farmfoundation.org/news/articlefiles/1028-1_harling.pdf.

16 B Miles, M. and Huberman, A M, Qualitative Data Analysis: A Sourcebook for New Methods (2nded.)., 2nd edn (Tousands Oaks, CA: SAGE, 1994). 
building because it prioritizes the character education values ${ }^{17}$. Even though not as big as some other schools in the regency, Christian Junior High School Seputih Raman has been nationally accredited B.

Encouraging by its vision "Qualified, Prosperous, Faithful", this school attempts to always increase the quality and affectivity of teaching and learning process by implementing studentcentered learning equipped with multi media and counseling services. In term of religious background, the school strongly accommodates the development of understanding and appreciation of the religion everyone in the school believes. It can be obviously seen from the vision which put the "Faithful" as one of the visions. Moreover, in the school's mission, it is implicitly written that the school fosters the appreciation and practice of the teachings of the religion they believe.

\section{Being moderate Muslims in the midst of Non-Muslim Majority}

In 2018, it is noted that at Christian Middle School Seputih Banyak, there were only 82 students consisting of 23 (28\%) Christians, 42 (51\%) Hindus which was the highest one, 8 (10\%) Buddhis, 7 (9\%) Muslims and the least one, Catholic, which was 2 (2\%) students. Meanwhile, there was only one Muslim teacher, a teacher of Islamic Religious Education subject. The majority of the students were Hindu because Seputih Raman is a village mostly inhabited by Balinese people. ${ }^{18}$

\footnotetext{
17 Maulidia Rachmawati Nur and Ahmad Madkur, 'Teachers' Voices on the 2013 Curriculum for English Instructional Activities', Indonesian Journal of English Education, 1.2 (2014), 119-34.

18 Meilani Puspitasari, 'Konversi Keagamaan Orang Bali Dari Agama Hindu Ke Agama Kristen: Studi Kasus Di Gereja Kristen Sumatera Bagian Selatan' (Universitas Kristen Satya Wacana, 2017). In 1955-1956 many Javanese, who took part in the transmigration program and lived around Seputih Raman. The transmigrants were from various religions such as Christianity, Catholicism, Islam, Hinduism and Buddhism.
} 
This only 7\% of the school's population undoubtedly obliged Muslims to adapt and respect the other believers and, in the same time, to be able to perform Islamic teachings and worship at the school. Muslim teacher and students had to build tolerant understanding to their non-Muslim teachers. Therefore, the Muslim teacher taught his students to be a moderate Muslim that co-exists harmoniously with other religions, acculturates local traditions and is compatible with democracy. ${ }^{19}$ Moderacy/ wasatiya/wasatiyya/wasathiyya) of Islam is commonly accepted as going hand-in-hand with tawazun (equilibrium, balance) and tasamuh (tolerance, flexiblitiy). ${ }^{20}$

At pedagogic level, practically, when Islamic religious education subject taught their students, he used to employ the materials, such as books, handouts, pictures and videos, containing the moderate Islamic values. The teaching strategies were considered effective because basically, Islamic values and messages should be instilled into all subject taught at schools. Also, to make the students understand and respect other cutures, the teachers integrated the local wisdoms, such as Lampung, Javanese, Balinese and others, into his instructional activities. ${ }^{21}$

When interacting with other believers in everiday lives at the school, Muslim teachers and students regularly participated the other religion's ritual ceremony, such as Christmas, Galungan, and Waisak. In addition, this habit was also performed outside of school activities. For example, in Chrismast day, they expressed Happy Christmas and visited the Christian Muslims. The same things were done to Hindus, Buddists and Catholics.

${ }^{19}$ A Ubaid and Muhammad Bakir, Nasionalisme Dan Islam Nusantara (Jakarta: Kompas, 2015).

20 A Sahal and A Munawir, Islam Nusantara. Dari Ushûl Fiqh Hingga Paham Kebangsaan (Bandung: Mizan, 2015).

${ }^{21}$ Ahmad Muzakki, 'Introducing Local Genius-Based Harmony Education (Piil Pesenggiri) Among the Indigenous People of Lampung', Penamas, 30.3 (2018), 261 <https://doi.org/10.31330/penamas.v30i3.188>. 


\section{The Promotion of Inter-religious Dialogue in Academic Lives}

\section{a. Peace-building Teaching and Learning Model}

Since the core of an educational institution is the teaching and learning process, the principal and the other stakeholders of the school seriously paid attention to not merely achieve the goal of material teaching but also equipping the student with mutual understanding and interfaith dialogue. As a result, the school developed and implemented the Peace-building Teaching and Learning model. This was an effort through formal education to prevent the widespread of conflicts in the society. This was a real contribution of the school to the peacemaking actions in the province of Lampung. It was widely known that Lampung is one of the regions in Indonesia with high number of conflicts. ${ }^{22}$

So what is Peace-building Teaching and Learning model? This model is inspired by the theory of and the practice of peace education ${ }^{23}$ in which all educators establish democratic classrooms that teach cooperation and promote positive self esteem among their students. Teachers serve as peaceful role models to help to counteract images of violent behaviour young people receive through popular culture and in their homes. Their teaching style adjusts to the developmental needs of their pupils, respecting the various identities and concerns about violence students bring to the classroom. ${ }^{24}$

The learning process is administered thematically. The principal approaches used in this model are, first, integrative instruction. It includes the implementation of non-violence sayings, behaviors and actions. This approcah stimulated the students not to bully their friends. As a result, according to

\footnotetext{
${ }^{22}$ Leydi Silvana, 'Pemetaan Daerah Rawan Konflik Di Provinsi Lampung', Jurnal Bina Praja, 05.03 (2016), 169-76 <https://doi.org/10.21787/jbp.05.2013.169-176>.

23 Zehavit Gross, 'Revisiting Peace Education: Bridging Theory and Practice International and Comparative Perspectives - Introduction', Research in Comparative and International Education, 12.1 (2017), 3-8 <https://doi.org/10.1177/ $1745499917698290>$.

${ }^{24}$ Rajshree, 'Peace Education Theory', SHIKSHAMITRA, 5.1 (2012), 51-53.
} 
the principal, the level of bulliying at this school was very low, different from many schools, both globally 25 and locally 26 , reporting the massive emergence of bulliying. The second approach was together learning. This includes reflecting, brainstorming, elaborating, exploring, and problem solving. The materials conveyed in this model were democracy, deliberation, peaceful co-existence, non-violence, and building non-violence community building.

The Peace-building Teaching and Learning model can be implemented in two scopes, integrative in formal learning and a shared learning approach in informal learning. Both can be developed with the main target of making a social-based and anti-violence school-based social community. In the first scope, the implementation of the Peace-building Teaching and Learning Model can be carried out with reference to the following design. ${ }^{27}$

Table 1. Integration of peace-building teaching in formal Setting

\begin{tabular}{|c|l|}
\hline \multicolumn{1}{|c|}{ Aspect } & \multicolumn{1}{c|}{ Descriptive Goal } \\
\hline $\begin{array}{l}\text { Symbolic } \\
\text { attribute }\end{array}$ & $\begin{array}{l}\text { To avoid using violent symbols, such as sharp } \\
\text { weapons. } \\
\text { To avoid using teaching material that shows symbols } \\
\text { of violence, such as images of torture or sexual } \\
\text { violence in textbooks. }\end{array}$ \\
\hline $\begin{array}{l}\text { Verbal } \\
\text { attribute } \\
\text { Verbal }\end{array}$ & $\begin{array}{l}\text { To avoid using words } \\
\text { harsh words, especially with motives } \\
\text { to harass, weaken, and insulting others, in teacher- } \\
\text { student and student relations }\end{array}$ \\
\hline $\begin{array}{l}\text { Constructive } \\
\text { attitude and } \\
\text { actions }\end{array}$ & $\begin{array}{l}\text { Getting used to "sorry, } \\
\text { please, and thank you "accordingly } \\
\text { with the context inside learning. } \\
\text { Building habits } \\
\text { understanding and }\end{array}$ \\
\hline
\end{tabular}

25 UNESCO, School Violence and Bullying Global Status Report Sustainable Development Goals United Nations Educational, Scientific and Cultural Organization, 2017 <https://doi.org/10.2105/AJPH.2011.300430>.

26 Zainudin Abu Bakar and Syafruddin M, 'The Importance of Social Support to Bullying Victims : A Case Study in Indonesia', in Ireland International Conference on Education, 2017, pp. 1-9.

27 Document Pembelajaran SMP Kristen Seputih Raman tahun 2015, p. 24 


\begin{tabular}{|l|l|}
\hline & $\begin{array}{l}\text { accepting differences } \\
\text { one another. } \\
\text { Using body language to reinforce gentleness (anti- } \\
\text { violence) } \\
\text { Confessing mistakes and apologizing for them. } \\
\text { Providing space for other people to make corrections } \\
\text { or improvements politely and civilized }\end{array}$ \\
\hline
\end{tabular}

In the second scope, namely with the "Collaborative Learning" approach in an informal learning, the aspects of competence that can be achieved through joint learning in a peace-building framework include doing/experiencing, expressing, analyzing, summarizing and applying. The implementation of the Peace-building Teaching and Learning Model in Raman Seputih Junior High School in Central Lampung was not only done once, but was carried out thematically by referring to the design and the following stages: ${ }^{28}$

Table 2. Integration of peace-building teaching in informal setting

\begin{tabular}{|l|l|l|c|}
\hline \multicolumn{1}{|c|}{ Stages } & \multicolumn{1}{|c|}{ Objectives } & Competence & Time \\
\hline $\begin{array}{l}\text { Geeting } \\
\text { started }\end{array}$ & $\begin{array}{l}\text { Teachers and students } \\
\text { prepare classrooms and } \\
\text { learning resources }\end{array}$ & $\begin{array}{l}\text { Planning, } \\
\text { participating }\end{array}$ & 5" \\
\hline $\begin{array}{l}\text { Implementat } \\
\text { ion: } \\
\text { Building } \\
\text { initial } \\
\text { atmosphere }\end{array}$ & $\begin{array}{l}\text { Intended to realize a sense } \\
\text { of togetherness and equality } \\
\text { among subjects of study } \\
\text { (teacher / facilitator, and } \\
\text { students) }\end{array}$ & $\begin{array}{l}\text { Doing, } \\
\text { experiencing, } \\
\text { expressing, }\end{array}$ & 10" \\
\hline $\begin{array}{l}\text { Reflecting/e } \\
\text { xploring/bra } \\
\text { instorming }\end{array}$ & $\begin{array}{l}\text { Inviting the students to } \\
\text { reflect on each other's } \\
\text { experiences or other } \\
\text { people's experiences as } \\
\text { "objects of suffering / } \\
\text { negative situations" caused } \\
\text { by other people's words, } \\
\text { attitudes, and behaviors. } \\
\text { Exploring and } \\
\text { brainstorming about this }\end{array}$ & $\begin{array}{l}\text { Doing, } \\
\text { experiencing, } \\
\text { analyzing, } \\
\text { concluding }\end{array}$ & 20 " \\
\end{tabular}

${ }^{28}$ Ibid, h. 50 


\begin{tabular}{|c|c|c|c|}
\hline & $\begin{array}{l}\text { experience was carried out } \\
\text { in a pattern: } 5 \mathrm{~W} 1 \mathrm{H} \text {. } \\
\text { Constructng resolutive or } \\
\text { healing measures for the } \\
\text { experience. }\end{array}$ & & \\
\hline $\begin{array}{l}\text { Analyze } \\
\text { certain } \\
\text { themes in } \\
\text { the } \\
\text { perspective } \\
\text { of "non } \\
\text { violence" }\end{array}$ & $\begin{array}{l}\text { Theme analysis can be done } \\
\text { through watching films, case } \\
\text { surgery, role playing, } \\
\text { modeling, and other } \\
\text { relevant activities that } \\
\text { contain content that } \\
\text { includes: democracy, } \\
\text { deliberation (deliberation), } \\
\text { peaceful co-existence, anti- } \\
\text { violence, and building an } \\
\text { anti-community non- } \\
\text { violence community } \\
\text { building. } \\
\text { The theme content is } \\
\text { adapted to the age and } \\
\text { psychology of junior high } \\
\text { school development. } \\
\text { The themes contain real } \\
\text { problems of violence that } \\
\text { can be analyzed. } \\
\text { The activity was continued } \\
\text { by jointly formulating an } \\
\text { attitude and ideal action to } \\
\text { respond to the situation of } \\
\text { the violence in the theme. }\end{array}$ & $\begin{array}{l}\text { Doing, } \\
\text { experiencing, } \\
\text { expressing, } \\
\text { analyzing, } \\
\text { concluding, } \\
\text { applying }\end{array}$ & $30 "$ \\
\hline $\begin{array}{l}\text { Authentic } \\
\text { assesement } \\
\text { and } \\
\text { reflection }\end{array}$ & $\begin{array}{l}\text { The subjects are stimulated } \\
\text { to propose opinions, dig up } \\
\text { attitudes, and express } \\
\text { actions through replicative } \\
\text { cases / similar to problems } \\
\text { in step. } \\
\text { The subjects are randomly } \\
\text { given the opportunity to } \\
\text { reflect on shared learning } \\
\text { experiences, both in terms } \\
\text { of content }\end{array}$ & $\begin{array}{l}\text { expressing, } \\
\text { concluding, } \\
\text { implementin } \\
\text { g }\end{array}$ & $15^{\prime \prime}$ \\
\hline
\end{tabular}

The bases for peacebuilding teaching and learning models are the principle of anti-violence, tolerance and antidiscrimination that will provide perspective and conceptual 
grounding in the development of demoratic and peaceful learning in learning classes.

\section{b. The availability of Worship Rooms and Teacher for all Religions}

Even though Christian Middle School Seputih Banyak has less students, compared to other schools in the regency, the stakeholders considered the significance of religious education teachers in interfaith dialogue amid the dversity of school community. For Muslim students, for instance, a teacher graduated from bachelor in Islamic education department of Institut Agama Islam Ma'arif (IAIM) Metro was hired. The reason why the school provided teachers for all religions is because they belive that the more the students understand their religions, the more possible they contribute to peacemaking. Religion is actually teaching peace. ${ }^{29}$

Religious subjects teaching and learning activities were carried out by each of their religious teachers, and the learning methods were adapted to the syllabus of each religious education material. As consequence, between teachers and students there has never been a conflict based on religion. Their multicultural understanding wa salso well established because of multicultural education ${ }^{30}$ at the school. They lived in harmony, peace and mutual respect for each other. Those students who embraced Islam were given the best opportunity to carry out their religious activities, among others, at the time of the dzuhur prayer, for example, we provided a prayer room for prayer. The same treatments were also applied to other religions.

\section{Conclusion}

To be well accepted as a minority, the Muslim teachers and students at Christian Middle School speutih Banyak successfully

${ }^{29}$ Susan Hayward, Religion and Peacebuilding Reflection on Current Challenges and Future Prospects, 2012 <http://www.usip.org/sites/default/files/SR313.pdf>.

30 Atin Supriatin and Aida Rahmi Nasution, 'Implementasi Pendidikan Multikultural Dalam Praktik Pendidikan Di Indonesia', Elementary: Jurnal Ilmiah Pendidikan Dasar, 3.1 (2017), 1 <https://doi.org/10.32332/elementary.v3i1.785>. 
adapted and, therefore, be respected by other religions. The findings of the research strengthen the previous research revealing that education is one of the most potential field to promote inter-religious dialogue and the urgency of peacemaking particularly to young generation.

At academic level, even though it seems demanding, the consistent and continuous implementation of peacebuilding-based instruction could succeed the goal of teaching and, in the same time, widen the students' insights on how to take a part in peacemaking actions.[]

\section{References}

Abdool, A, F Potgieter, J L Van Der Walt, and C Wolhuter, 'Inter-Religious Dialogue in Schools : A Pedagogical and Civic Unavoidability', HTS Teologiese Studies, 63 (2007), 543-60 <https://doi.org/DOI: 10.4102/hts.v63i2.211>

Azra, Azyumardi, 'Indonesian Islam, Mainstream Muslims and Politics in Taiwan', in Taiwanese and Indonesian Islamic Leaders Exchange Project (Taiwan: The Asia Foundation, 2006), pp. 1-11

Bagir, Zainal Abidin, 'Interfaith Dialogue and Religious Education', in Asia-?-Europe Meeting (ASEM) 4th Interfaith Dialogue, 2008, pp. 19

Bakar, Zainudin Abu, and Syafruddin M, 'The Importance of Social Support to Bullying Victims : A Case Study in Indonesia', in Ireland International Conference on Education, 2017, pp. 1-9

Brajovic, Zoran, 'The Potential of Inter-Religious Dialogue', in Peacebuilding and Civil Society in Bosnia- Herzegovina, ed. by Martina Fischer, 2006, pp. 185-214

Gross, Zehavit, 'Revisiting Peace Education: Bridging Theory and Practice - International and Comparative Perspectives Introduction', Research in Comparative and International Education, 12 (2017), 3-8 <https://doi.org/10.1177/ 17454999 17698290> 
Hayward, Susan, Religion and Peacebuilding Reflection on Current Challenges and Future Prospects, 2012 <http://www.usip.org/ sites/default/files/SR313.pdf>

Hefner, Robert W, Civil Islam, Princeton: Princeton University Press, 2000

Holland, Claire, 'Interfaith Dialogue and Higher Education : Education for Peace', Journal of the Tertiary Campus Ministry Association, 6 (2016), 1-8

Karim, Khairulnizam Mat, and Suzy Aziziyana Saili, 'Role of Religious Leader in Interfaith Dialogue towards Conflict Role of Religious Leader in Interfaith Dialogue towards Conflict Resolution: A Muslim Analysis on Christianity's Perspective', in International Conference on Social Science Research, ICSSR, 2015, pp. 273-88

Madkur, Ahmad, and Azkia Muharom Albantani, 'Instilling Islamic Values in Foreign Language Teaching: An Indonesian Context', Advances in Social Science, Education and Humanities Research, 115 (2018), 97-103 <https://doi.org/10.2991/icems-17.2018. 20>

Miles, M., B, and Huberman, A M, Qualitative Data Analysis: A Sourcebook for New Methods (2nded.)., 2nd edn, Tousands Oaks, CA: SAGE, 1994

Muzakki, Ahmad, 'Introducing Local Genius-Based Harmony Education (Piil Pesenggiri) Among the Indigenous People of Lampung', Penamas, 30 (2018), 261 <https://doi.org/10.31330/penamas. v30i3.188>

Ni'am, Syamsun, 'Pesantren: The Miniature of Moderate', IJIMS, Indonesian Journal of Islam and Muslim Societies, 5 (2015), 111-34

Nicolai, Susan, and Carl Triplehorn, The Role of Education in Protecting Children in Conflict (London: Humanitarian Practice Network (HPN), 2003) 
Nur, Maulidia Rachmawati, and Ahmad Madkur, 'Teachers' Voices on the 2013 Curriculum for English Instructional Activities', Indonesian Journal of English Education, 1 (2014), 119-34

Puspitasari, Meilani, 'Konversi Keagamaan Orang Bali Dari Agama Hindu Ke Agama Kristen: Studi Kasus Di Gereja Kristen Sumatera Bagian Selatan' (Universitas Kristen Satya Wacana, 2017)

Rajshree, 'Peace Education Theory', SHIKSHAMITRA, 5 (2012), 51-53

Sahal, A, and A Munawir, Islam Nusantara. Dari Ushûl Fiqh Hingga Paham Kebangsaan, Bandung: Mizan, 2015.

Sahrasad, Herdi, 'Herdi Sahrasad Indonesian Pluralism And Democracy Under Challenge: A Social Reflection', AL_FIKR, 20 (2016), 256-78

Schlehe, Judith, and Eva Nisa, The Meanings of Moderate Islam in Indonesia: Alignments and Dealignments of Azharites, Occasional Paper Series (Freiburg, 2016) <https://www.researchgate.net /deref/http\%3A\%2F\%2Fwww.southeastasianstudies.unifreiburg.de\%2Fpublications\%2Fop-series $>$

Silvana, Leydi, 'Pemetaan Daerah Rawan Konflik Di Provinsi Lampung', Jurnal Bina Praja, 05 (2016), 169-76 <https://doi.org/10.21787/ jbp.05.2013.169-176>

Supriatin, Atin, and Aida Rahmi Nasution, 'Implementasi Pendidikan Multikultural Dalam Praktik Pendidikan Di Indonesia', Elementary: Jurnal Ilmiah Pendidikan Dasar, 3 (2017), $1<$ https:// doi.org/10.32332/elementary.v3i1.785>

Ubaid, A, and Muhammad Bakir, Nasionalisme Dan Islam Nusantara, Jakarta: Kompas, 2015

Umar, Ahmad Rizky Mardhatillah, 'A Genealogy of Moderate Islam: Governmentality and Discourses of Islam in Indonesia's Foreign Policy', Studia Islamika, 23 (2016), 399-433

UNESCO, School Violence and Bullying Global Status Report Sustainable 
Development Goals United Nations Educational, Scientific and Cultural Organization, 2017 <https://doi.org/10.2105/AJPH. 2011.300430>

Wandusim, Michael Fuseini, 'Interfaith Dialogue and Christian Witness: Exploring the Challenges and Tensions Involved From a Ghanaian Perspective', Journal of Advocacy, Research and Education, 3 (2015), 19-20

Zuhdi, Muhammad, 'Challenging Moderate Muslims: Indonesia's Muslim Schools in the Midst of Religious Conservatism', Religions, 9 (2018), 1-15 <https://doi.org/10.3390/rel9100310> 